\title{
Importance and Potential Advantages of Web-based Corporate Disclosure in Jordan: Current Status and Future Aspirations
}

\author{
Fawzi A. Al Sawalqa (Corresponding Author) \\ Accounting Department, Business Faculty, Tafila Technical University, Box 179, Tafila \\ 66110 , Jordan \\ E-mail: fsawalqah@ttu.edu.jo \\ Jebreel Al-Msiedeen \\ Accounting Department, Business Faculty, Tafila Technical University, Tafila, Jordan \\ E-mail: Dr.Jebreel@ttu.edu
}

Received: Jan. 14, 2021 Accepted: Feb. 20, 2021 Published: March 11, 2021

doi:10.5296/bmh.v9i1.18200 URL: https://doi.org/10.5296/bmh.v9i1.18200

\begin{abstract}
The study examines the perceptions of accounting information users toward the importance of a web-based disclosure for 32 items and the potential advantages for both the users and companies. The study also investigates the perceptions of users regarding the websites presentation and the obstacles of web-based disclosure. In addition, the study examines empirically the relationship between the importance of web-based disclosure and the potential advantages for both users and companies. Based on 107 online users' responses, results show that financial information is the most important information that should be disclosed on the websites of companies according to users. Results also show that the mean values of the advantages for both users and companies are, high, close and significant. Users' perceptions indicate that competition, cost and audit issues are the main obstacles that may hinder companies to use websites for disclosure. In addition, findings show a positive and significant relationship between the "financial" factor and the users' potential advantages. In respect to the companies' potential advantages, results show that both "human resources and suppliers" factor and "the governance, quality and strategy" factor have positive and significant relationship with the companies' potential advantages. Accordingly, decision-makers should effectively use the seven factors that extracted from principle
\end{abstract}




\section{Macrothink}

Business and Management Horizons

ISSN 2326-0297

2021, Vol. 9, No. 1

component analysis as a web-based disclosure model to create advantages for both users and companies.

Keywords: web-based disclosure, accounting information users, web-based importance, potential advantages, website presentation 


\section{Introduction}

The effective dissemination of corporate information through the websites aids in the flow of information to several places and users easily (Lodhia, Allam, \& Lymer, 2004; Portella \& Bora, 2020), in a timely manner (Ashbaugh, Johnstone, \& Warfield, 1999) and supports the transparency of firm (Nel \& Baard, 2019; Andrea et al., 2020). In general, the disclosure of compulsory accounting information is satisfactory, especially among western countries like Japan (e.g., Marston, 2003), Australia (e.g., Lodhia et al., 2004) and Canada (e.g., Cormier, Aerts, Ledoux, \& Magnan, 2010), and even in some emerging markets like Turkey (e.g., Bozcuk et al., 2011), Gulf countries (e.g., Al-Sartawi, 2016) and Malaysia (Khan, 2016), while the level of voluntary reporting is, in general, unacceptable, especially in developing countries. In particular, Western countries have outperformed developing countries in web-based reporting. This is because the corporate governance instructions inspire the web-based reporting in developed countries (Smith \& Pierce, 2005; Aly et al., 2010; Sánchez et al., 2011). In context of Jordan, the legislative body in Jordan put little weight to the web-based disclosure and only the Corporate Governance Code for Shareholding Companies which issued by Jordan Securities Commission (JSC) asked companies to use their websites for reporting in paragraph (D) of Article 14 (JSC, 2017). In this context, it is important to improve the web-based reporting process through appropriate regulations (Victoria \& Nicoleta, 2008; Sánchez et al., 2011) and not to leave it to the managements (Sánchez et al., 2011).

It has been found that the web-based disclosure is different from one country to another (Lymer, Debreceny, Gray, \& Rahman, 1999; Khadaroo, 2005; Al-Sartawi, 2016) and even from one firm to another (FASB, 2000; Ashbaugh et al., 1999; Al - Htaybat, 2011) due to the different used strategies (Keliwon, Shukor, Mohamed, \& Hassan, 2014) and the variations in web-based disclosure features (Dyczkowska, 2014). Thus, the quality and importance of the accounting information that posted on the websites of any company is identified through several qualitative characteristics as outlined in prior studies. For example, Smith and Pierce (2005) focused on the integrity of online disclosed information by stressing the importance of following the best governance practices in the web-based financial reporting. Abdelsalam, Bryant and Street (2007) focused on the content, credibility and usability of internet disclosure and the determinants of such disclosure. Chatterjee and Hawkes (2008) stressed the importance of accessibility of online information as a factor that can facilitate the comparability value among countries. Dyczkowska (2014) focused on the quality of web-based reporting in terms of completeness, accuracy, relevance and transparency. Al-Sartawi (2016) and Khan (2016) focused on the content and presentation dimensions of internet disclosed information. However, earlier studies neglected the perception of users toward the different issues of IFR (Khan, Ismail, Mardani, Zavadskas \& Kaklauskas, 2017), and focused mainly on the secondary date to identify the determinants of IFR. For example, several studies have focused on identifying the determinants of internet corporate disclosure in Jordan (e.g., AbuGhazaleh, Qasim \& Roberts, 2012; Momany, Al-Malkawi, \& Mahdy, 2014; Yassin, 2017) and other developing countries (e.g., Hossain, Momin, \& Leo, 2012; Yao, Nurunnabi, \& Hossain, 2012; Basuony \& Mohamed, 2014; Omran \& Ramdhony, 2016). In 
addition, some companies are reluctant to disclose specific types of information such as customers and employees information (e.g., Lodhia et al., 2004), forward-looking information (e.g., Sriram \& Laksmana, 2006; Sánchez et al., 2011), products or services quality (e.g., Álvarez, Sanchez \& Dominguez, 2008; Fuertes-Callén, Cuellar-Fernández, \& Pelayo-Velázquez, 2014), strategic information (e.g., Sánchez et al., 2011) and innovation (e.g., Cormier et al., 2010).

Consequently, the current knowledge in web-based reporting is in need for further studies to know the perceptions of users toward the types of information that they need to find on the internet and the websites of firms, the advantages of online reporting for both the users and firms, and the barriers that prevent companies from disclosing some types of information online. In addition, the web-based reporting prior studies are in need for additional studies to take the perception of users toward the design of firms' websites. This is also the cases in Jordan where prior study by Momany et al. (2014) indicated that Jordanian companies try to give more emphasis to the web-based reporting in general as $69 \%$ of Jordanian companies have web sites, which forms a notable improvement in using internet by Jordanian companies even when compared with other companies in other developing countries. In light of this truth, it is the appropriate time to investigate the perceptions of Jordanian users toward the web-based reporting. Therefore, the current study comes as a new addition to the current literature to close these gaps especially in developing emerging markets. In particular, this study surveyed the users of accounting information to achieve the following objectives:

1) To identify the perception of users toward the importance of web-based disclosure for a set of items.

2) To identify the perception of users toward the potential advantages of web-based disclosure for both users and companies.

3) To identify the perception of users toward the obstacles that may prevent companies to use websites for disclosure.

4) To identify the perceptions of users toward:

a. The extent of updating the web-based information.

b. The most used tools for communication to give feedback to companies on the data disclosed on the website

c. The most used formats to browse the web-based information.

5) To identify if there is any association between the importance of web-based disclosure and the potential advantages for both users and companies.

The current study contributes to prior literature in the filed as it is considered one of the first studies that examined empirically the relationship between the importance of web-based disclosure and the potential advantages for both users and companies. In addition, the study offers a new web-based disclosure model contain seven factors extracted from principle component analysis based on the perceptions of users. In addition, the study classified 32 
items accordance to their importance to users. This, also, helps companies to arrange their priorities in web-disclosure. Furthermore, the study presents the perceptions of users toward important issues in web-based disclosure such as potential advantages and obstacles. Finally, the study also identifies the current status of some website presentation issues such as updating, communication and browsing.

The reminder of the paper is structured as follows. Section two presents the relevant literature. Section three presents the methodology of study. Section four discusses the findings of study. And finally, section five concludes the study.

\section{Literature Review}

Generally speaking, the relevant prior studies for the current study are those that have focused on the importance, advantages, barriers and design of websites from the perceptions of users. Unfortunately, these types of studies are very rare (Al-Htaybat, Alberti-Alhtaybat, \& Hutaibat, 2011) as most of prior studies investigated the determinants and level of website disclosure using secondary data.

\subsection{Web-Based Disclosure Practices}

Most of prior studies focused on the internet or web-based disclosure level and ignored the perception of users in this context. Accordingly, this section examines the web-based reporting as outlined in previous studies. For example, Lymer et al. (1999) performed a study for International Accounting Standards Committee (IASC) by examining the annual reports of 660 companies from 22 countries and found that about $86 \%$ have websites and 410 firms strived to disclose some financial information, with 234 firms disclosed necessary financial information on their websites. In the same context, findings of Victoria and Nicoleta (2008) revealed that 51 firms of 110 European firms strived to disclose some information on websites. FASB (2000) performed a study to identify the level of internet reporting of 325 items in USA. In general, results show that 99 firms have websites and have several patterns in web-based disclosure. The authors found that only $58 \%$ disclosed complete annual reports on websites. Marston (2003) examined 99 Japanese firms and found that 78 firms have home pages and 68 reported financial information on internet. Lodhia et al. (2004) examined the websites of 50 Australian firms to determine the internet reporting level over 36 items. For example, results indicated that information about employees is not disclosed, but the financial statements are disclosed. Khadaroo (2005) found that Singapore firms outperform Malaysia firms in internet reporting for financial and investor information. Based on 212 U.S companies distributed between high technology and traditional firms, Sriram and Laksmana (2006) results revealed that of the 26 items, only about half were disclosed websites. Álvarez et al. (2008) found that the entire study sample (117 firms) has websites, with 50\% disclosed compulsory information and $25 \%$ disclosed voluntary information (see also, Aly et al., 2010). Cormier et al. (2010) and Bozcuk et al. (2011) results show that the web-based disclosure is, in general, enhanced with time for mandatory information and some categories. Sánchez et al. (2011) results indicated that Spanish companies disclosed partially some strategic information on websites. Puspitaningrum and Atmini (2012) investigated the internet disclosure practices and determinants among 95 Indonesian companies. Authors' findings 
indicated that internet disclosure among Indonesian companies is, in general, low. Fuertes-Callén et al. (2014) investigated the level and types of information disclosed on the websites of a sample of Latin American listed companies in three countries including Argentina, Chile and Mexico and the determinants of such disclosure. Findings of study revealed that listed companies in the three countries interested in posting the compulsory accounting information on their websites. Based on a sample of 92 Turkish companies, Çalışkan and Güler (2014) developed a disclosure index including 74 items to investigate the level and determents of internet disclosure. Authors' findings show that the level of disclosure is satisfactory, especially for the financial information. Tarik et al. (2015) investigated the internet financial reporting practices of 88 companies in Bosnia and Herzegovina. Based on 30 items from 6 categories the results show that the internet disclosure is very weak. For example, only $30 \%$ of the study sample disclosed the balance sheet and only $28 \%$ disclosed the profit and loss statement. Other financial information like statement of cash flows is disclosed by only $20 \%$ of the study sample. Authors justified such results based on the notion that developing markets are in general suffering weaknesses in corporate governance practices (e.g., Ojah \& Mokoaleli-Mokoteli, 2012). Al-Sartawi (2016) results indicated a satisfactory level of internet disclosure among Gulf countries. Similar result also found by Khan (2016) for Malaysian firms (see also, Waweru, Mangena, \& Riro, 2019). Other studies revealed several results for the web-based disclosure. For example, it was moderate in Bananuka et al. (2019) for Malaysian firms (see also, Alarussi \& Shamkhi, 2020), and about $76 \%$ for Saudi banks in Sarea (2020).

\subsection{Advantages and Obstacles of Web-Based Disclosure}

Prior studies show benefits and also outlined many concerns toward web-based disclosure. For example, Joshi and Al - Modhahki (2003) show that web-based disclosure is timeliness, while findings of Khan and Ismail (2012) show that web-based disclosure is important in enhancing investments, transparency, accountability and efficiency (see also, Khan et al., 2013). In the same context, Ashbaugh et al. (1999) show that web-based disclosure is necessary for firms, customers and shareholders. Some prior studies also expressed some concern about the web-based disclosure. The security concern was reported by some prior studies (e.g., Joshi \& Al - Modhahki, 2003; Smith \& Pierce, 2005; Khan \& Ismail, 2012; Khan et al., 2013). The shortage of skillful expertise is also reported in some studies (e.g., Smith \& Pierce, 2005; Khan \& Ismail, 2012). In addition, prior studies reported some awareness about the cost and design of websites (e.g., Ashbaugh et al., 1999; Khan et al., 2013).

\subsection{Website Presentation}

The website should be presented in a way the enables users to access information smoothly (Pirchegger \& Wagenhofer, 1999; Marston \& Polei, 2004; Smith \& Pierce, 2005). Therefore, prior studies investigated, for example, the updating frequency of web-based information, communications tools and browsing format. For example, several studies (e.g., Çalışkan \& Güler, 2014; Khan, 2016; Pinto \& Picoto, 2016; Dolinšek \& Lutar-Skerbinjek, 2018; Sandhu $\&$ Singh, 2019; Sarea, 2020) found that PDF is the main format for disclosing information on 
websites. In respect to the updating frequency, results of prior studies show lack of interest in updating. For example, only $3.3 \%$ of the firms are interested in updating the website information in Çalışkan and Güler (2014). Further, findings of Pinto and Picoto (2016) indicated that only $20 \%$ of the pages display the latest update. In the same context, Sandhu and Singh (2019) results show that about $64.29 \%$ of companies used to update information on websites during a period of more than one week. In respect to the communication tool, findings of Pinto and Picoto (2016) show that both e-mail and phone are used equally, while findings of D'Andrea et al. (2019) and Dolinšek and Lutar-Skerbinjek (2018) show that e-mail is common tool for contact.

\subsection{Jordan Context}

In context of Jordan, several studies have investigated the web-based disclosure practices in Jordan. For example, Momany and Al-Shorman (2006) investigated 60 Jordanian listed companies to identify the level of internet disclosure practices among such companies and found that only 27 companies have web sites. And only 19 of them did disclose some types of financial information on their web sites. In particular, authors' findings indicated that of the 19 companies only 6 companies disclosed full financial information. Al-Hayale (2010) found that only $30 \%$ of Jordanian industrial companies used a web-based disclosure. Author's findings also indicated that web-based disclosure is useful for investors. Al-Htaybat et al. (2011) found that, in general, the users support the importance of internet reporting for decision-making. Al - Htaybat (2011) found that that the internet reporting among Jordanian is acceptable, while findings of AbuGhazaleh et al. (2012) show unacceptable level (see also, Momany et al., 2014). However, Yassin (2017) found a moderate level of web-based disclosure practices among Jordanian companies.

\subsection{Final Remarks on Prior Literature}

Investigation of prior studies on web-based disclosure practices revealed many notable remarks. First, there was inconsistency in the disclosure pattern even at the level of a country itself (e.g., Ashbaugh et al., 1999; Dyczkowska, 2014; Ferreira \& Martins, 2017; Waweru, Mangena \& Riro, 2019) and at the level of the region across homogeneous countries (e.g., Ojah \& Mokoaleli-Mokoteli, 2012; Al-Sartawi, 2016). Second, there was also inconsistency in the disclosure strategies followed by each company (e.g., Keliwon et al., 2014), which may justify partially the inconsistency in the online disclosure pattern. Third, the web-based reporting suffers two main problems. Firstly, unavailability of a well-known model for web-based reporting (e.g., Trabelsi, Labelle, \& Laurin, 2004; Sriram \& Laksmana, 2006). Secondly, lacking of international standards (Victoria \& Nicoleta, 2008) and regulations (e.g., Dyczkowska, 2014; Al-Sartawi, 2016) necessary to govern and organize the scope of web-based disclosure. In particular, the absence of regulations made the web-based reporting voluntary and based mainly on the management policy of a company (e.g., Marston, 2003; Japan Sriram \& Laksmana, 2006; Bui \& Sankaran, 2009; Sánchez et al., 2011). This, however, affected the prior studies in online disclosure as most of them were descriptive in nature (e.g., Marston, 2003; Trabelsi et al., 2004; Khan \& Ismail, 2011; Khan et al., 2013) with mixed results for those that investigated the determinants of such disclosure. Fourth, 
prior studies revealed that some companies are reluctant to disclose some important items (e.g. Sriram \& Laksmana, 2006; Álvarez et al., 2008; Cormier et al., 2010; Sánchez et al., 2011; Çalışkan \& Güler, 2014). Finally, results of prior studies revealed that companies tend to disclose more mandatory information than the voluntary information (Lodhia et al., 2004; Álvarez et al., 2008; Bozcuk et al., 2011; Fuertes-Callén et al., 2014).

Accordingly, the current study comes to explore the perceptions of users toward several issues in this topic on the basis that they are the ones who must determine the nature of such disclosure.

\section{Methodology}

\subsection{Sample and Data}

The population of the current study includes the users of accounting information. Accordingly, a well-developed questionnaire was sent online to such users. 118 respondents were filled out the questionnaire. 11 unusable questionnaires were excluded. This yields 107 usable questionnaires. The questionnaire includes 8 sections. The first section interests in the demographic characteristics of the respondents. Section 2 asks respondents to rank 32 items (B1-B32) according to the importance of web disclosure for each item on a five-point likert scale $(1=$ not importance at all; $5=$ very importance). These items were taken from prior studies in the field (e.g., Pirchegger \& Wagenhofer, 1999; Williams \& Pei, 1999; Ettredge, Richardson, \& Scholz, 2001; Marston \& Polei, 2004; Lee, Neilson, Tower, \& Van der Zahn, 2007; Álvarez et al., 2008; Cormier et al., 2010; Sánchez et al., 2011; Fuertes-Callén et al., 2014). The third section seeks to investigate the perception of users toward the advantages of internet disclosure for users. The section includes seven advantages (C1-C7) adapted from prior research in the field (e.g., Joshi \& Al - Modhahki, 2003; Al-Htaybat et al., 2011; Khan \& Ismail, 2012; Khan, Ismail, \& Zakuan, 2013). A five-point likert scale also used (1= strongly disagree; $5=$ strongly agree). Similarly, section four focuses on the advantages of internet disclosure for firms and includes 11 advantages. 9 of them (D1-D7, D9 and D11) were adapted from prior studies (e.g., Joshi \& Al - Modhahki, 2003; Khan \& Ismail, 2012; Khan, Ismail, \& Zakuan, 2013), while 2 advantages (D8 and D10) were added by researchers. Section five seeks to investigate the perception of users toward the obstacles that may face and hinder the internet disclosure. This section includes 7 obstacles. 5 of them (E1-E5) adapted from prior research in the field (e.g., Lymer et al., 1999; Joshi \& Al - Modhahki, 2003; Khan \& Ismail, 2012; Khan, Ismail, \& Zakuan, 2013), and 2 items (E6 and E7) were adapted from FASB (2000). Section six has one question (F) interested in the updated frequency of web-disclosed information (e.g., Çalışkan \& Güler, 2014; Sandhu \& Singh, 2019). Section seven interested in the communication ways with firms and includes 3 ways (G1-G3) taken from Feldioreanua and Seriaa (2015). Finally, section eight seeks to investigate the perceptions of users toward the frequency of using 3 formats (H1-H3) to browse the web-based disclosed information (e.g., Lodhia, Allam, \& Lymer, 2004; Çalişkan $\&$ Güler, 2014). All these sections based on a five-point-likert scale. The study instrument also includes an open-end question asks respondents to express their opinion on the study instrument and the topic of study. Table 1 shows the demographic characteristics of the 
respondents. About $95.3 \%$ of the respondents aged 30 years or above. This however, is an important indicator about the accumulated experiences of respondents. About $36.4 \%$ of the respondents are managers, 9.3\% are accountants and 5.6\% are academics. The others section includes, for example, merchants, engineers and others. $22.4 \%$ of respondents are specialized in accounting and 20.6\% have business administration degrees. Most important, about $80.3 \%$ of the respondents have a bachelor degree or above.

Table 1. Demographic information

\begin{tabular}{llllll}
\hline Demographic & Frequency & $\%$ & Demographic & Frequency & $\%$ \\
\hline Age & & & Majoring & \\
less than 30 & 5 & 4.7 & Accounting & 24 & 22.4 \\
30- less than 40 & 23 & 21.5 & Business Administration & 22 & 20.6 \\
40-less than 50 & 44 & 41.1 & Economy & 9 & 8.4 \\
50 years and above & 35 & 32.7 & Finance & 2 & 1.9 \\
Total & 107 & 100.0 & Others & 50 & 46.7 \\
Position & & & Total & 107 & 100.0 \\
Manager & 39 & 36.4 & Qualification & & \\
Accountant & 10 & 9.3 & PhD & 4 & 3.7 \\
Auditor & 1 & .9 & MSc & 16 & 14.9 \\
Academic & 6 & 5.6 & BSc & 66 & 61.7 \\
Student & 3 & 2.8 & Diploma & 16 & 15.0 \\
Others & 48 & 44.9 & Secondary school & 5 & 4.7 \\
Total & 107 & 100.0 & Total & 107 & 100.0 \\
\hline
\end{tabular}

\subsection{Factor Analysis and Reliability of Variables}

Principle Component Analysis is performed for the 32 disclosure items (Hair, Black, Babin, $\&$ Anderson, 2014). Prior studies in this field suggested several dimensions to web-based disclosure (e.g., Pirchegger \& Wagenhofer, 1999; Williams \& Pei, 1999; Ettredge et al., 2001; Marston \& Polei, 2004; Lee et al., 2007; Álvarez et al., 2008; Cormier et al., 2010; Sánchez et al., 2011; Fuertes-Callén et al., 2014). As shown in Table 2, 7 factors are extracted with eigenvalues greater than 1 using Varimax with Kaiser Normalization. 6 items (B4, B9, B10, B16, B21 and B29) were deleted. B10 and B21 were deleted due to cross-loading on two factors, while the other items were deleted as they have loadings less than 0.50 . The extracted factors include 26 items distributed over 7 factors. Factor 1 includes 6 items (B27, B28, B31, B32, B30 and B26) and represents human resources and suppliers information. Theoretically, there is a close relationship between suppliers and human resources in any firm. In this context, Wagner (2006) stressed the importance of supporting suppliers through the human resources. Factor 2 includes 6 items (B19, B17, B18, B12, B22 and B11) and represents governance, quality and strategy information. In this context, Zahra (1990) discussed in details the theoretical relationship between corporate governance and strategy through the effective role that directors may play in identifying the strategic polices of firm. Therefore, it can be argued that governance, quality and strategy can be combined together. Factor 3 
includes 4 items (B8, B7, B23 and B20) and represents dividend, alliances and competition information. It can be argued that alliances create dividends for firms and also support their competitive advantage in market. Therefore, it is easy to combine alliances with dividend and competition. Factor 4 includes 3 items (B14, B13 and B15) and represents social responsibility information. Factor 5 includes also 3 items (B2, B1 and B3) and represents financial information. Factor 6 includes 2 items (B5 and B6) and represents share prices. Factor 7 includes 2 items (B25 and B24) and represents risk and production process information. The 7 factors explain about $74.534 \%$ of the variance in the web-based disclosure items. The Kaiser-Meyer-Olkin Measure of Sampling Adequacy and Bartlett's Test of Sphericity are in the appropriate levels.

Table 2. Principle component analysis results

\begin{tabular}{|c|c|c|c|c|c|c|c|c|}
\hline No & Item & F 1 & F 2 & F 3 & F 4 & F 5 & F 6 & F 7 \\
\hline B27 & An employee profile & .835 & & & & & & \\
\hline B28 & Employee training programs & .806 & & & & & & \\
\hline B31 & Information on employment policies & .742 & & & & & & \\
\hline B32 & The employee turnover rate & .738 & & & & & & \\
\hline B30 & Information about employee health and safety & .732 & & & & & & \\
\hline B26 & Supplier networks description & .713 & & & & & & \\
\hline B19 & Objectives, mission and philosophy of the company & & .760 & & & & & \\
\hline B17 & $\begin{array}{l}\text { Quality and safety of the services or products } \\
\text { offered }\end{array}$ & & .738 & & & & & \\
\hline B18 & Information on commercial products and services & & .725 & & & & & \\
\hline B12 & Audit committee information & & .722 & & & & & \\
\hline B22 & Annual plan of company & & 689 & & & & & \\
\hline B11 & Board of Directors information & & .621 & & & & & \\
\hline B8 & Dividend of prior years & & & .835 & & & & \\
\hline B7 & Current year dividend & & & .759 & & & & \\
\hline B23 & Description of the competition & & & .671 & & & & \\
\hline B20 & Information about strategic alliances & & & .591 & & & & \\
\hline B14 & Information about donations and sponsorships & & & & .856 & & & \\
\hline B13 & Information about corporate social responsibility & & & & .803 & & & \\
\hline B15 & Information about environmental or social activities & & & & .702 & & & \\
\hline B2 & $\begin{array}{l}\text { Balance sheet, income statement and statement of } \\
\text { cash flows of the previous years }\end{array}$ & & & & & .896 & & \\
\hline B1 & $\begin{array}{l}\text { Balance sheet, income statement and statement of } \\
\text { cash flows of current year }\end{array}$ & & & & & .867 & & \\
\hline B3 & Interim information about current year & & & & & .671 & & \\
\hline B5 & Current year share price & & & & & & .893 & \\
\hline B6 & Prior years share prices & & & & & & .760 & \\
\hline B25 & Information about production processes & & & & & & & .680 \\
\hline B24 & Information about risks & & & & & & & .652 \\
\hline \multicolumn{2}{|c|}{ Eigenvalue } & 8.819 & 3.272 & 1.972 & 1.507 & 1.438 & 1.289 & 1.082 \\
\hline \multicolumn{2}{|c|}{ Explained variance $(\%)$} & 33.920 & 12.586 & 7.584 & 5.795 & 5.531 & 4.958 & 4.160 \\
\hline \multicolumn{2}{|c|}{ Cronbach's Alpha } & .911 & .881 & .792 & .856 & .831 & .722 & .441 \\
\hline $\begin{array}{l}\text { Total } \\
\text { Kaise } \\
\text { Bartle }\end{array}$ & $\begin{array}{l}\text { variance explained }=74.534 \% \\
\text {-Meyer-Olkin Measure of Sampling Adequacy }=0.80 \\
\mathrm{tt} \text { 's Test of Sphericity }=1814.489 ; \mathrm{p}=0.000\end{array}$ & Kaiser-Meyer-Olkin Measure of Sampling Adequacy $=0.800$ & & & & & & \\
\hline
\end{tabular}

Table 2 also shows that Cronbach alpha values for all factors. Except the risk and production factor $(0.441<0.700)$, all the Cronbach alpha values are in the accepted levels (Sekaran \& Bougie, 2016). Therefore, risk and production factor will not be included in the regression for analysis. 


\subsection{Research Hypotheses and Theoretical Models}

Based on the objectives of the study and the results of principle component analysis, the following hypotheses were developed:

H1. According to users, the web-based disclosure for different items is significantly important.

H2. Users have positive perceptions toward the potential advantages of web-based disclosure for users.

H3. Users have positive perceptions toward the potential advantages of web-based disclosure for companies.

Based on the results of principle component analysis, the following hypotheses were also developed:

H4. There is a significant and positive relationship between the importance of web-based disclosure for different disclosure factors and the potential advantages for users.

In addition, six sub-hypotheses were derived from $\mathrm{H} 4$ :

H4a. There is a significant and positive relationship between the importance of web-based disclosure for human resources and supplier information and the potential advantages for users.

$\mathrm{H} 4 \mathrm{~b}$. There is a significant and positive relationship between the importance of web-based disclosure for governance, quality and strategy information and the potential advantages for users.

H4c. There is a significant and positive relationship between the importance of web-based disclosure for dividend, alliances and competition information and the potential advantages for users.

$\mathrm{H} 4 \mathrm{~d}$. There is a significant and positive relationship between the importance of web-based disclosure for social responsibility information and the potential advantages for users.

H4e. There is a significant and positive relationship between the importance of web-based disclosure for financial information and the potential advantages for users.

H4f. There is a significant and positive relationship between the importance of web-based disclosure for share price information and the potential advantages for users.

H5. There is a significant and positive relationship between the importance of web-based disclosure for different disclosure factors and the potential advantages for companies.

Similarly, six sub-hypotheses were derived from H5:

H5a. There is a significant and positive relationship between the importance of web-based disclosure for human resources and supplier information and the potential advantages for companies. 


\section{Macrothink}

Business and Management Horizons

ISSN 2326-0297

2021, Vol. 9, No. 1

H5b. There is a significant and positive relationship between the importance of web-based disclosure for governance, quality and strategy information and the potential advantages for companies.

H5c. There is a significant and positive relationship between the importance of web-based disclosure for dividend, alliances and competition information and the potential advantages for companies.

H5d. There is a significant and positive relationship between the importance of web-based disclosure for social responsibility information and the potential advantages for companies.

H5e. There is a significant and positive relationship between the importance of web-based disclosure for financial information and the potential advantages for companies.

H5f. There is a significant and positive relationship between the importance of web-based disclosure for share price information and the potential advantages for companies.

Figure 1 shows the theoretical model of study. In particular, it includes 6 independent variables and two dependent variables. Based on this model, two regression models will be developed to test the relationship between the independent variables and each dependent variable.

Web-based disclosure/independent variables

1. Human resources and supplier information

2. Governance, quality and strategy information

3. Dividend, alliances and competition information

4. Social responsibility information

5. Financial information
Dependent variables

1. Potential advantages for users.

2. Potential advantages for companies.

Figure 1. Theoretical model of study

\section{Results and Discussion}

\subsection{Importance of Web-Based Disclosure}

The first objective of the current study tries to identify the importance of web-based corporate reporting for a set of items according to users. Table 3 shows the means, standard deviations, ranks and the results of One-Sample T-Test. The current year dividend is considered the most important item (4.5514) that companies should disclose on their websites among the 32 items according to users. This result is normal as investors are interested in the return on their 


\section{Macrothink}

investments in the first instance. The financial statements of the current year ranked second with a mean of 4.5047 and followed by interim information of the current year with a mean of 4.3832. These two results give an indicator about the importance of financial information for users. These results are also consistent with the findings of prior studies that investigated the actual web-based disclosure practices (e.g., Marston, 2003; Lodhia et al., 2004; Fuertes-Callén et al., 2014; Çalışkan \& Güler, 2014; Khan, 2016; Ferreira \& Martins, 2017). The users are also interested in the board of director information, which ranked fourth with a mean of 4.3551. This result is also an important indicator about the importance of corporate governance information to users. Users also see that companies should disclose their plan on their websites to get clear picture about the future of company. Dividend of prior years and the financial statements of prior years are ranked six and followed by the information about the risks that may face the company. However, the results also show that users give little importance to the web disclosure of human resource and corporate social responsibility information. For example, the last four items are related to the human resource and social responsibility categories. These results are consistent with that of Fuertes-Callén et al. (2014) who found that employee profile is one of the least disclosed items.

According to One-Sample T-Test and except for employee profiles (B27) and environmental or social activity information (B15), all the means are significant at $\mathrm{p}<0.05$. 
Table 3. The importance of web-based corporate disclosure for a set of items according to users

\begin{tabular}{|c|c|c|c|c|c|c|}
\hline No & Item & Mean & S.D & Rank & t-value & Sig \\
\hline B7 & Current year dividend & 4.5514 & 0.64769 & 1 & 24.777 & 0.000 \\
\hline B1 & $\begin{array}{l}\text { Balance sheet, income statement and statement of } \\
\text { cash flows of current year }\end{array}$ & 4.5047 & 0.80533 & 2 & 19.327 & 0.000 \\
\hline B3 & Interim information about current year & 4.3832 & 0.72222 & 3 & 19.811 & 0.000 \\
\hline B11 & Board of Directors information & 4.3551 & 0.74292 & 4 & 18.868 & 0.000 \\
\hline B22 & Annual plan of company & 4.3364 & 0.80028 & 5 & 17.274 & 0.000 \\
\hline B8 & Dividend of prior years & 4.3178 & 0.72161 & 6 & 18.890 & 0.000 \\
\hline B2 & $\begin{array}{l}\text { Balance sheet, income statement and statement of } \\
\text { cash flows of the previous years }\end{array}$ & 4.3178 & 0.90698 & 6 & 15.029 & 0.000 \\
\hline B24 & Information about risks & 4.3084 & 0.67867 & 8 & 19.942 & 0.000 \\
\hline B5 & Current year share price & 4.2617 & 0.75656 & 9 & 17.250 & 0.000 \\
\hline B21 & Strategic planning of company & 4.2523 & 0.81372 & 10 & 15.920 & 0.000 \\
\hline $\mathrm{B} 25$ & Information about production processes & 4.1495 & 0.73720 & 11 & 16.130 & 0.000 \\
\hline B12 & Audit committee information & 4.0467 & 1.06738 & 12 & 10.144 & 0.000 \\
\hline B4 & Interim information about prior years & 4.0467 & 0.71879 & 12 & 15.063 & 0.000 \\
\hline B18 & Information on commercial products and services & 4.0280 & 0.88444 & 14 & 12.024 & 0.000 \\
\hline B23 & Description of the competition & 4.0187 & 0.77680 & 15 & 13.565 & 0.000 \\
\hline B20 & Information about strategic alliances & 4.0187 & 0.90054 & 15 & 11.701 & 0.000 \\
\hline B17 & $\begin{array}{l}\text { Quality and safety of the services or products } \\
\text { offered }\end{array}$ & 3.9720 & 0.96601 & 17 & 10.408 & 0.000 \\
\hline B29 & Information about remunerations and incentives & 3.9720 & 0.98534 & 17 & 10.204 & 0.000 \\
\hline B6 & Prior years share prices & 3.9346 & 0.94441 & 19 & 10.236 & 0.000 \\
\hline B9 & Full report on corporate governance & 3.8411 & 0.98239 & 20 & 8.857 & 0.000 \\
\hline $\mathrm{B} 10$ & Organizational chart & 3.7196 & 0.96929 & 21 & 7.680 & 0.000 \\
\hline B19 & Objectives, mission and philosophy of the company & 3.7009 & 1.10073 & 22 & 6.587 & 0.000 \\
\hline B26 & Supplier networks description & 3.6168 & 0.93813 & 23 & 6.801 & 0.000 \\
\hline B16 & $\begin{array}{l}\text { Information about research and development } \\
\text { projects }\end{array}$ & 3.5514 & 1.01157 & 24 & 5.639 & 0.000 \\
\hline B31 & Information on employment policies & 3.4019 & 1.11474 & 25 & 3.729 & 0.000 \\
\hline B13 & Information about corporate social responsibility & 3.4019 & 1.05383 & 25 & 3.945 & 0.000 \\
\hline B32 & The employee turnover rate & 3.3645 & 1.08500 & 27 & 3.475 & 0.001 \\
\hline B28 & Employee training programs & 3.2804 & 1.06217 & 28 & 2.730 & 0.007 \\
\hline $\mathrm{B} 30$ & Information about employee health and safety & 3.2243 & 1.05784 & 29 & 2.193 & 0.030 \\
\hline B14 & Information about donations and sponsorships & 3.2150 & 1.06424 & 30 & 2.089 & 0.039 \\
\hline $\mathrm{B} 27$ & An employee profile & 3.1776 & 0.94981 & 31 & 1.934 & 0.056 \\
\hline \multirow[t]{2}{*}{ B15 } & $\begin{array}{l}\text { Information about environmental or social } \\
\text { activities }\end{array}$ & 2.9813 & 1.06382 & 32 & -0.182 & 0.856 \\
\hline & & 3.8829 & & & & \\
\hline
\end{tabular}

\subsection{Advantages to Users}

The second objective comes to identify the potential advantages of web-based corporate reporting for both users and companies. Table 4 shows the perceptions of users toward the potential advantages for them. It looks that enhancing the timeliness of getting information is ranked first with a mean of 4.4393 . This followed by enhancing the information efficiency. These two advantages necessarily enhance the decision-making process which ranked third. These results are consistent with the findings of Khan, Ismail and Zakuan (2013). Users also 
see that web-based disclosure increases the quantity of available information and facilitate comparison. These two advantages were ranked fourth and fifth respectively. Reducing costs of getting information ranked six with a mean of 4.1308. Finally, diversify the disclosure tools ranked seventh with a mean of 4.0374. This result is almost consistent with the findings of Al-Htaybat et al. (2011) and Khan and Ismail (2012). All the seven advantages were given close approvals ranged from a mean value of 4.4393 for the first ranked advantage to 4.0374 for the last ranked advantage on a five-point-likert scale (e.g., Khan \& Ismail, 2012). In addition, the total mean is high (4.2911) and all the mean values of advantages are significant $(p=0.000)$. These results give a critical indicator about the importance of web-based disclosures for users in Jordan.

Table 4. The potential advantages of web-based disclosure for users

\begin{tabular}{lllllll}
\hline No & Item & Mean & S.D. & Rank & t-value & Sig \\
\hline C1 & Enhance the timeliness of getting information & 4.4393 & 0.68924 & 1 & 21.600 & 0.000 \\
C2 & Increase information efficiency & 4.4206 & 0.63003 & 2 & 23.324 & 0.000 \\
C7 & Enhance the decision-making process & 4.3645 & 0.66436 & 3 & 21.245 & 0.000 \\
C3 & Increase the quantity of available information & 4.3458 & 0.68821 & 4 & 20.228 & 0.000 \\
C4 & Facilitate the comparability of information & 4.2991 & 0.66183 & 5 & 20.304 & 0.000 \\
C5 & Reduce the cost of getting information & 4.1308 & 0.81361 & 6 & 14.377 & 0.000 \\
C6 & Offers another mean of disclosure & 4.0374 & 0.83469 & 7 & 12.856 & 0.000 \\
Total & & 4.2911 & & & & \\
\hline
\end{tabular}

\subsection{Advantages to Companies}

Table 5 shows the perceptions of users toward the potential advantages of web-based corporate reporting for companies. Similar to the advantages for users, the responses of users are close to each other and ranged from promoting firms internally and externally (4.6168) to encouraging harmonization in accounting practices (4.0280), with a total mean of 4.3908 . These results exceed those of prior research in the field (e.g., Khan \& Ismail, 2012; Khan, Ismail, \& Zakuan, 2013). However, the results show that promoting companies ranked first with a mean of 4.6168. This result is almost consistent with that of Khan, Ismail and Zakuan (2013) which ranked second. Attracting local investments comes second. This result is also consistent with the findings of Khan, Ismail and Zakuan (2013), but contradicts that of Khan and Ismail (2012) which ranked fifth. Consistent with the findings of Khan and Ismail (2012), enhancing transparency ranked third. In general, users see that web-based disclosure is very useful to Jordanian companies as it, for example, promotes companies, attracts local investments and enhances transparency, performance, accountability and efficiency. In addition, all the 11 advantages are significant $(p=0.000)$. 
Table 5. The potential advantages of web-based disclosure for companies

\begin{tabular}{lllllll}
\hline No & Item & Mean & S.D. & Rank & t-value & Sig \\
\hline D2 & Promote firms internally and externally & 4.6168 & .65365 & 1 & 25.586 & .000 \\
D3 & Attract local investments & 4.6075 & .62581 & 2 & 26.570 & .000 \\
D4 & Enhance transparency & 4.5888 & .64359 & 3 & 25.536 & .000 \\
D1 & Attract foreign investments & 4.5514 & .75528 & 4 & 21.248 & .000 \\
D5 & Attract potential customers & 4.4673 & .69115 & 5 & 21.960 & .000 \\
D11 & promote accountability & 4.4486 & .66210 & 6 & 22.632 & .000 \\
D7 & enhance financial performance & 4.4019 & .77532 & 7 & 18.703 & .000 \\
D6 & Enhance managerial efficiency & 4.3364 & .81198 & 8 & 17.025 & .000 \\
D9 & Decrease the costs of disclosure process & 4.1402 & .91578 & 9 & 12.879 & .000 \\
D8 & Enhance the governance practices & 4.1121 & .86141 & 10 & 13.355 & .000 \\
D10 & Encourage the harmonization in accounting & 4.0280 & .84069 & 11 & 12.649 & .000 \\
& practices & & & & & \\
Total & & 4.3908 & & & & \\
\hline
\end{tabular}

\subsection{Obstacles of Web-Based Disclosure}

The third objective of the current study tries to identify the obstacles that may prevent companies to use websites for disclosure according to users. The perceptions of users toward the worries and obstacles that may hinder companies to use websites for disclosures are outlined in Table 6. Three obstacles are ranked first with a mean value of 3.7196 for each of them. These include worries about competition, cost and audit. These results are almost similar to the findings of Khan and Ismail (2012) in mean values but different in rankings. One justification for such results, for example, is that some companies may worry from other competitors in the market and refrain from disclosing some important information. In this context, Çalışkan and Güler (2014) found a great conservatism in disclosing some information such as the planned sales and earnings (see also, Sánchez et al., 2011). Similarly, Al-Htaybat et al. (2011) argued that costs limit the internet reporting practices in Jordan. According to users, companies may have also some concerns and worries related to legal requirements, security (e.g., Smith \& Pierce, 2005; Khan, \& Ismail, 2012; Khan, Ismail, \& Zakuan, 2013) and accounting standards. Unexpected result is that users in Jordan give the security issue low weight comparing to other studies in the field (e.g., Joshi \& Al - Modhahki, 2003; Khan et al., 2017). However, the total mean of all the responses is 3.6636 and all the seven obstacles are significant. 
Table 6. The obstacles that may prevent companies to use websites for reporting

\begin{tabular}{lllllll}
\hline No & Item & Mean & S.D. & Rank & t-value & Sig \\
\hline E4 & Issues related to competition & 3.7196 & .99806 & 1 & 7.458 & .000 \\
E2 & Issues related to cost & 3.7196 & 1.09712 & 1 & 6.785 & .000 \\
E7 & Issues related to audit & 3.7196 & 1.14755 & 1 & 6.487 & .000 \\
E5 & Issues related to Legal requirements & 3.6916 & .97527 & 4 & 7.335 & .000 \\
E1 & Issues related to information security & 3.6822 & 1.11252 & 5 & 6.343 & .000 \\
E6 & Issues related to accounting standards & 3.6168 & 1.07848 & 6 & 5.916 & .000 \\
E3 & Issues related to website design & 3.4953 & 1.10209 & 7 & 4.649 & .000 \\
Total & & 3.6636 & & & & \\
\hline
\end{tabular}

\subsection{Web-Based Information Updating}

The first part of objective four focuses on the extent of updating the web-based information according to users. Table 7 shows that $32.7 \%$ of respondents say "sometimes", $28 \%$ say "often" and $17.8 \%$ say "always". These results along with the mean value (3.3551) indicate that updating the web information comes in a moderate level. Investigating the prior results indicated almost similar results (e.g., Sandhu \& Singh, 2019; Sarea, 2020) or less (e.g., Çalışkan \& Güler, 2014; Pinto \& Picoto, 2016). These, results are not acceptable and companies should give the updating process more emphasis in Jordan.

Table 7. The extent of updating the web-based information

\begin{tabular}{llllllll}
\hline & \% Never & \% Rarely & \% Sometimes & \% Often & \% Always & Mean & S.D \\
\hline $\begin{array}{l}\text { Frequency of } \\
\text { updating }\end{array}$ & 6.5 & 15.0 & 32.7 & 28.0 & 17.8 & 3.3551 & 1.13480 \\
\hline
\end{tabular}

\subsection{Tools of Communication}

The second part of objective four focuses on the tools of communication with companies to give feedback on the data disclosed on the websites. As shown in table 8, the most used tool is company phone. The justification for such result is based on the idea than phone contact is easy and user can immediately make sure that the idea is delivered to the concerned person. Other studies (e.g., Pinto \& Picoto, 2016) show similar results. However, companies should reactivate their emails to enable users to get written responses to their comments in order for such companies to promote transparency and accountability. 


\section{Macrothink}

Table 8. Tools of communication with companies

\begin{tabular}{llll}
\hline No. & Communication tool & Mean & S.D \\
\hline G2 & Company phone & 3.2056 & 1.07052 \\
G1 & E-mail address of the company & 2.6168 & 1.17878 \\
G3 & Visiting company & 2.4953 & 1.12748 \\
\hline
\end{tabular}

\subsection{Format of Browsing}

The last part of objective four asks about the most used formats to browse the web-based information. Table 9 shows that PDF is the most used format with a mean of 3.4019. This result is consistent with the findings of several prior studies (e.g., Lodhia et al., 2004; Çalışkan \& Güler, 2014; Álvarez et al., 2008; Khan, 2016; Sandhu \& Singh, 2019).

Table 9. The most used formats to browse the web-based information

\begin{tabular}{llll}
\hline No. & Format & Mean & S.D \\
\hline H1 & PDF-format & 3.4019 & 1.07159 \\
H2 & Word-format & 2.4206 & 1.04644 \\
H3 & Video files & 2.0374 & 1.14038 \\
\hline
\end{tabular}

\subsection{Hypotheses Testing}

The first three hypotheses were tested using One-sample T-test. H 4 and H5 were tested using linear multiple regression.

\subsubsection{One-Sample-T-Test}

According to users, $\mathrm{H} 1$ proposes that the web-based disclosure for different items is significantly important. As shown in Table 10, One-sample T-test result indicates that the mean (3.8829) is significant $(t=17.204 ; \mathrm{p}=0.000)$. Accordingly, $\mathrm{H} 1$ is accepted. This, however, indicates that users have positive perceptions toward the importance of web-based disclosure for different items. This also indicates that users consider the web-based disclosure necessary. One important justification of such result is the results of One-sample T-test for different items that shown in Table 3 above. Table 3 shows that 30 items of 32 have significant means.

H2 proposes that users have positive perceptions toward the potential advantages of web-based disclosure to users. Similarly, Table 10 shows that the mean (4.2911) is positive and significant $(\mathrm{t}=24.803 ; \mathrm{p}=0.000)$. Accordingly, $\mathrm{H} 2$ is accepted. This means that users have positive perceptions toward the potential advantages of web-based disclosure to users. This result is supported by the results of One-sample T-test that reported in Table 4, where all the 7 potential advantages have mean values greater than four and are all significant. In addition, this result is consistent with that of Khan et al. (2017). 
$\mathrm{H} 3$ also proposes that users have positive perceptions toward the potential advantages of web-based disclosure to companies. Result of One-sample T-test show that the means value (4.3908) is positive and significant $(\mathrm{t}=26.444 ; \mathrm{p}=0.000)$. Accordingly, H3 is accepted. This result shows that users have positive perceptions toward the potential advantages of web-based disclosure to companies. This result is supported by the results that shown in Table 5 above, where all the 11 potential advantages have mean values greater than four and are all significant. This result is also consistent with that of Khan et al. (2017).

Table 10. One-sample T Test results

\begin{tabular}{lllll}
\hline $\mathrm{H}$ & Mean & S.D & t-value & Sig \\
\hline H1: Importance of web-based disclosure. & 3.8829 & .53085 & 17.204 & .000 \\
H2: Potential advantages of web-based disclosure for users. & 4.2911 & .53844 & 24.803 & .000 \\
H3: Potential advantages of web-based disclosure for companies. & 4.3908 & .54405 & 26.444 & .000 \\
\hline
\end{tabular}

\subsubsection{Multiple Regression Analysis}

Based on the results of principle component analysis, seven factors were extracted. Accordingly, $\mathrm{H} 4$ and its sub-hypotheses and H5 and its sub-hypotheses will be tested using multiple regressions. Notability that factor 7 will not be included in the regression due to the low reliability. Table 11 shows the descriptive statistics for the 7 factors and the potential advantages for users and companies. In particular, the most important factor according to the users is the financial factor with a mean of 4.4019. This result is consistent with prior research findings in respect to the actual disclosure (e.g., Lymer et al., 1999; Marston, 2003). Accordingly, multiple regressions are used to show the relationship between the importance of such factors and the potential advantages for both users and companies.

Table 11. Descriptive statistics for the study variables

\begin{tabular}{lllll}
\hline Factor & No. of items & Cronbach’s Alpha & Mean & S.D \\
\hline Factor 1: Human resources and suppliers & 6 & .911 & 3.3442 & .86186 \\
Factor 2: Governance, quality and strategy & 6 & .881 & 4.0732 & .74154 \\
Factor 3: Dividend, alliances and competition & 4 & .792 & 4.2266 & .60221 \\
Factor 4: Social responsibility & 3 & .856 & 3.1994 & .93484 \\
Factor 5: Financial information & 3 & .831 & 4.4019 & .70449 \\
Factor 6: Share prices & 2 & .722 & 4.0981 & .75685 \\
Factor 7: Risk and production process & 2 & .441 & 4.2290 & .56752 \\
Advantages to users & 7 & .872 & 4.2911 & .53844 \\
Advantages to company & 11 & .908 & 4.3908 & .54405 \\
\hline
\end{tabular}


Table 12 shows the correlation matrix. The correlation coefficients indicate the absence of Multicollinearity problem among the explanatory variables.

Table 12. Correlation Matrix

\begin{tabular}{lllllll}
\hline Factor & HUSU & GOQS & DILC & SORP & FINL & SHPR \\
\hline HUSU & 1 & & & & & \\
GOQS & $.617^{* *}$ & 1 & & & & \\
DILC & $.379^{* *}$ & $.448^{* *}$ & 1 &. & & \\
SORP & $.563^{* *}$ & $.520^{* *}$ & $.309^{* *}$ & 1 & & \\
FINL & .028 & $.221^{*}$ & $.376^{* *}$ & -.043 & 1 & \\
SHPR & $.247^{*}$ & $.246^{*}$ & $.370^{* *}$ & .174 & $.238^{*}$ & 1 \\
\hline
\end{tabular}

Note. ${ }^{* *}$ Correlation is significant at the 0.01 level. $*$ Correlation is significant at the 0.05 level.

H4 proposes that there is a positive relationship between the importance of web-based disclosure for different categories and the potential advantages for users. 6 factors were entered in the regression model as shown in equation 1.

$$
\text { ADUSERS }=\beta_{0}+\beta_{1} H U S U+\beta_{2} G O Q S+\beta_{3} D I L C+\beta_{4} S O R P+\beta_{5} F I N L+\beta_{6} S H P R+e
$$

Where:

ADUSERS $=$ users' potential advantages; HUSU = human resources and suppliers factor; GOQS = governance, quality and strategy factor; DILC = dividend, alliances and competition factor; SORP $=$ Social responsibility; FINL = financial factor; SHPR $=$ share prices factor; and $\mathrm{e}=$ error term.

The independent variables are the six extracted factors and the dependent variable is the users' potential advantages. As shown in Table 13, the model is significant $(\mathrm{F}=3.358 ; p$ $=.005)$. However, the values of means for Cook's Distance and Centered Leverage value indicate that the regression is free of outliers. Both the values of tolerance (TOL) and variance inflation factor (VIF) indicate the absence of Multicollinearity problem (Tol > zero, and VIF < 10) (Sekaran \& Bougie, 2016).

The empirical results indicate that only the financial factor is associated with the users' potential advantages factor. In particular, the financial factor has a positive and significant $(\mathrm{t}$ $=1.983 ; \mathrm{p}=0.05)$ relationship with the users' potential advantages. Accordingly, $\mathrm{H} 4 \mathrm{e}$ is accepted. Therefore, there is a significant and positive relationship between the importance of web disclosure for financial information and the potential advantages for users. That is, the importance of disclosing financial information through the websites of Jordanian companies creates advantages for users. This result is very realistic, since users are primarily interested in financial information as shown in the descriptive statistic results. In addition, the availability of financial information gives users timely information to take investment decisions. To the best of our knowledge, no prior studies investigated such relationships. 


\section{Macrothink}

Thus, other studies that found the web-based disclosure for financial information is dominants may support our result (e.g., Çalışkan \& Güler, 2014; Khan, 2016; Ferreira \& Martins, 2017).

Other sub-hypotheses ( $\mathrm{H} 4 \mathrm{a}, \mathrm{H} 4 \mathrm{~b}, \mathrm{H} 4 \mathrm{c}, \mathrm{H} 4 \mathrm{~d}$ and $\mathrm{H} 4 \mathrm{f}$ ) are rejected as results show insignificant relationships with the users' potential advantages factor. The justification for such results is due to the fact that other information such as human resources, governance and social responsibility information concern the employees, companies and public more than users, who interested much in financial information.

Table 13. Multiple regression analysis results

\begin{tabular}{lllll}
\hline Independent variables & t-value & Sig. & Tol. & VIF \\
\hline (Constant) & 5.907 & .000 & & \\
HUSU & 1.645 & .103 & .518 & 1.931 \\
GOQS & -.685 & .495 & .511 & 1.956 \\
DILC & 1.475 & .143 & .645 & 1.550 \\
SORP & .718 & .474 & .613 & 1.632 \\
FINL & 1.983 & $.050^{*}$ & .781 & 1.281 \\
SHPR & .271 & .787 & .834 & 1.199 \\
R & .410 & & & \\
$\mathrm{R}^{2}$ & .168 & & & \\
Adjusted R & .118 & & & \\
F & 3.358 & & & \\
Sig. & .005 & & & \\
Cook's Distance & .016 & & & \\
Centered Leverage Value & .056 & & & \\
Durbin-Watson & 1.712 & & & \\
\hline
\end{tabular}

Note. Dependent variable: Users' potential advantages. * Significant at the 0.10 level.

As shown in equation 2, the regression repeated with the companies' potential advantages as a dependent variable to test H5a, H5b, H5c, H5d, H5e and H5f.

$$
A D C O M P S=\beta_{0}+\beta_{1} H U S U+\beta_{2} G O Q S+\beta_{3} D I L C+\beta_{4} S O R P+\beta_{5} F I N L+\beta_{6} S H P R+e
$$

Where:

ADCOMPS = companies' potential advantages; HUSU = human resources and suppliers factor; GOQS = governance, quality and strategy factor; DILC = dividend, alliances and competition factor; SORP $=$ Social responsibility; FINL $=$ financial factor; SHPR $=$ share prices factor; and $\mathrm{e}=$ error term.

H5 proposes a positive relationship between the importance of web-based disclosure for different categories and the potential advantages for companies. The results of regression for 
the six sub-hypotheses are shown in Table 14. H5a proposes a significant and positive relationship between the importance of web-based disclosure for human resources and supplier information and the potential advantages for companies. Result shows a positive and significant $(t=1.736 ; p=0.086)$ relationship between human resources and supplier factor and the potential advantages for companies. Accordingly, H5a is accepted. This means that there is a significant and positive relationship between the importance of web disclosure for human resources and supplier factor and the potential advantages for companies. The main justification for such result is that both employees and suppliers are the main drivers to any firm operating activities. Thus, disclosing information on websites about them creates advantages for companies according to the users.

The results also show a positive and significant $(\mathrm{t}=1.730 ; \mathrm{p}=0.087)$ relationship between governance, quality and strategy information and the companies' potential advantages. Therefore, H5b is accepted. Thus, it can be concluded that there is a significant and positive relationship between the importance of web-based disclosure for governance, quality and strategy factor and the potential advantages for companies. This means that disclosing governance, quality and strategy information on companies websites creates potential advantages for such companies such as attracting local and foreign investments, promoting companies and enhancing transparency and accountability. This result is realistic as the governance, quality and strategy information include such information about the durability of corporate governance, quality of production and services and the future plan of company that will create potential advantages for companies. In addition, the strategic information includes plans for future periods and the business managers are responsible for implementation. However, other factors have insignificant relationships with the companies' potential advantages. Therefore, other hypotheses (H5c, H5d, H5e and H5f) are rejected. A possible justification for such results is that disclosing of other information is formality to satisfy certain parties and to comply with legal requirements.

Table 14. Multiple Regression Analysis Results

\begin{tabular}{lllll}
\hline Independent variables & t-value & Sig. & Tol. & VIF \\
\hline (Constant) & 6.592 & .000 & & \\
HUSU & 1.736 & $.086^{*}$ & .518 & 1.931 \\
GOQS & 1.730 & $.087^{*}$ & .511 & 1.956 \\
DILC & -.011 & .991 & .645 & 1.550 \\
SORP & .321 & .749 & .613 & 1.632 \\
FINL & .514 & .608 & .781 & 1.281 \\
SHPR & .777 & .439 & .834 & 1.199 \\
R & .449 & & & \\
$\mathrm{R}^{2}$ & .202 & & & \\
Adjusted R & & & & \\
F & .154 & & & \\
Sig. & 4.207 & & & \\
Cook's Distance & .001 & & & \\
Centered Leverage Value & .015 & & & \\
Durbin-Watson & .056 & & & \\
\hline
\end{tabular}

Note. Dependent variable: Companies' potential advantages. * Significant at the 0.10 level. 


\section{Conclusion and Recommendations}

The current study is one of the few studies that interested in the perception of users toward the importance of a web-based disclosure for 32 items. The study also focused on the perceptions of users toward the potential advantages of web-based disclosure for both the users and companies. In addition, the study shows the perception of users toward the obstacles that may prevent companies to use websites for reporting. Furthermore, the study is interested in the website presentation issues as identified by users. Principle component analysis was initially used to determine the main components of web-based disclosure items as ranked by the users. Finally, the relationship between the importance of web-based disclosure for 6 factors and the potential advantages for both users and companies was empirically tested. These objectives were achieved through online responses from 107 users.

According to the users, results revealed that financial information is the most important information that should be disclosed on the websites of companies. This information includes, for example, current year dividend, the financial statements and the current year interim information. The social responsibility information is the least important according to the users. Results also show that web-based disclosure has several potential advantages for users. These include, for example, enhancing the timeliness and efficiency of information. In addition, web-based disclosure enhances the decision-making process. In respect to companies, results also show that web-based disclosure is also very useful. Examples of the highest ranked advantages for companies include promoting companies, attracting investments and enhancing transparency. However, results show that mean values of advantages for both the users and companies are close to each other and significant. In respect to the obstacles, users see that competition, cost and audit issues are the main obstacles that may hinder companies to use their websites for reporting. In respect to the websites presentation, users indicate that updating the web information comes in a moderate level, and the phone is the main communication tool, with the PDF as the main browsing format.

Empirical results indicate that users have positive and significant perceptions toward the importance of web-based disclosure. In addition, results indicate that users have positive and significant perceptions toward both the potential advantages of web-based disclosure for users and companies. In respect to the regression results, findings show a significant and positive relationship between the financial factor and the users' potential advantages. In respect to the companies' potential advantages, results show a significant and positive relationship between the importance of web-based disclosure for "human resources and suppliers" factor and the companies' potential advantages. In addition, results show a significant and positive relationship between "the governance, quality and strategy" factor and the companies' potential advantages.

Based on the perceptions of users, the current exploratory study presents up-to-date valuable information to decision-makers in Jordanian companies in respect to web-based disclosure. First, the study tabulates 32 items accordance to their importance to users, which is supposed to assist companies in directing their web-based disclosure in the right direction. Second, the 
principle component analysis resulted in seven factors that can be used as a web-based disclosure model by companies. Third, the obstacles of web-based disclosure received fewer weights than the potential advantages for both users and companies in a five-point-likert scale, which indicates a high tendency for users to move towards web-based disclosure. Accordingly, companies should support such tendency by intensive web-based disclosure. Finally, the empirical results indicate that most of the web-based disclosure factors are not associated with the potential advantages for both users and companies. This, however, lays additional responsibility on Jordanian companies to support such relation by giving more emphasis to the quality of web-based disclosure in the first instance.

The low study sample is the main limitation for the current study. Accordingly future studies may use larger samples and compare the perception of users with that of business managers, for example, to enrich this topic. In addition, future studies in Jordan may incorporate more items to evaluate the web-based disclose in terms of integrity, accessibility and accuracy. Furthermore, future studies may be performed to compare the status of web-based disclosure in Jordan with that in other developing and developed countries.

\section{References}

Abdelsalam, O. H., Bryant, S. M., \& Street, D. L. (2007). An examination of the comprehensiveness of corporate internet reporting provided by London-listed companies. Journal of International Accounting Research, 6(2), 1-33. https://doi.org/10.2308/jiar.2007.6.2.1

AbuGhazaleh, N. M., Qasim, A., \& Roberts, C. (2012). The determinants of web-based investor relations activities by companies operating in emerging economies: The case of Jordan. Journal of Applied Business Research, 28(2), 209-226. https://doi.org/10.19030/jabr.v28i2.6842

Al-Hayale, T. (2010). Financial reporting on the internet in the Middle East: The case of Jordanian industrial companies. International Journal of Accounting and Finance, 2(2), 171-191. https://doi.org/10.1504/IJAF.2010.032087

Al-Htaybat, K. (2011). Corporate online reporting in 2010: A case study in Jordan. Journal of Financial Reporting and Accounting, 9(1), 5-26. https://doi.org/10.1108/19852511111139778

Al-Htaybat, K., von Alberti-Alhtaybat, L., \& Hutaibat, K. A. (2011). Users' Perceptions on Internet Financial Reporting Practices in Emerging Markets: Evidence from Jordan. International Journal of Business and Management, 6(9), 170-182. https://doi.org/10.5539/ijbm.v6n9p170

Al-Sartawi, M. (2016). Measuring the level of online financial disclosure in the Gulf Cooperation Council Countries. Corporate Ownership \& Control, 14(1), 547-558. https://doi.org/10.22495/cocv14i1c4art1

Alarussi, A. S., \& Shamkhi, D. (2020). Company characteristics, dominant personalities in board committees and internet financial disclosures by Malaysian listed companies. Malaysian Management Journal, 20, 59-75. https://doi.org/10.32890/mmj.20.2016.9041 
Álvarez, I. G., Sanchez, I. M. G., \& Dominguez, L. R. (2008). Voluntary and compulsory information disclosed online: The effect of industry concentration and other explanatory factors. Online Information Review, 32(5), 596-622. https://doi.org/10.1108/14684520810913990

Aly, D., Simon, J., \& Hussainey, K. (2010). Determinants of corporate internet reporting: Evidence from Egypt. Managerial Auditing Journal, 25(2), 182-202. https://doi.org/10.1108/02686901011008972

Ashbaugh, H., Johnstone, K. M., \& Warfield, T. D. (1999). Corporate reporting on the Internet. Accounting Horizons, 13(3), 241-257. https://doi.org/10.2308/acch.1999.13.3.241

Bananuka, J., Night, S., Ngoma, M., \& Najjemba, G. M. (2019). Internet financial reporting adoption: Exploring the influence of board role performance and isomorphic forces. Journal of Economics, Finance and Administrative Science, 24(48), 266-287. https://doi.org/10.1108/JEFAS-11-2018-0120

Basuony, M. A., \& Mohamed, E. K. (2014). Determinants of internet financial disclosure in GCC countries. Asian Journal of Finance \& Accounting, 6(1), 70-89. https://doi.org/10.5296/ajfa.v6i1.5085

Bozcuk, A. E., Aslan, S., \& Arzova, S. B. (2011). Internet financial reporting in Turkey. EuroMed Journal of Business, 6(3), 313-323. https://doi.org/10.1108/14502191111170141

Bui, T., \& Sankaran, S. (2009). E-disclosure of financial information and the capacity to borrow. Academy of Accounting \& Financial Studies Journal, 13(1), 33-52.

Çalişkan, A. Ö., \& Güler, H. (2014). Corporate Reporting on the Internet: An Investigation on Turkish Listed Companies. Marmara Üniversitesi İktisadi ve İdari Bilimler Dergisi, 36(2), 251-274. https://doi.org/10.14780/iibd.21098

Chatterjee, B., \& Hawkes, L. (2008). Does internet reporting improve the accessibility of financial information in a global world? A comparative study of New Zealand and Indian companies. Australasian Accounting, Business and Finance Journal, 2(4), 33-56. https://doi.org/10.14453/aabfj.v2i4.3

Cormier, D., Aerts, W., Ledoux, M. J., \& Magnan, M. (2010). Web-based disclosure about value creation processes: a monitoring perspective. Abacus, 46(3), 320-347. https://doi.org/10.1111/j.1467-6281.2010.00321.x

D’Andrea, A., Pizzichini, L., Marasca, S., \& Gregori, G. L. (2019). CSR Communication: The Use of Internet-Based Tools. Symphonya. Emerging Issues in Management, 2, 38-59. https://doi.org/10.4468/2019.2.05dandrea.pizzichini.marasca.gregori

Dolinšek, T., \& Lutar-Skerbinjek, A. (2018). Voluntary disclosure of financial information on the internet by large companies in Slovenia. Kybernetes, 47(3), 458-473. https://doi.org/10.1108/K-08-2016-0220

Dyczkowska, J. (2014). Assessment of Quality of Internet Financial Disclosures Using a 
Scoring System. A Case of Polish Stock Issuers. Accounting and Management Information Systems, 13(1), 50-81.

Ettredge, M., Richardson, V. J., \& Scholz, S. (2001). The presentation of financial information at corporate Web sites. International Journal of Accounting Information Systems, 2(3), 149-168.https://doi.org/10.1016/S1467-0895(00)00017-8

FASB. (2000). Electronic distribution of business reporting information. Business Reporting Research Project, Steering Committee Report Series. Retrieved from http://www.fasb.org/brrp/brrp1.shtml

Feldioreanua, I. A., \& Seriaa, C. (2015). Corporate governance disclosure of banks in Romania and Malaysia and the quality of the web sites. Accounting and Management Information Systems, 14(1), 193-216.

Ferreira, T. S. V., \& Martins, O. S. (2017). Relationship analysis between disclosure on the internet, risk and return in Latin American companies. RAM. Revista de Administração Mackenzie, 18(2), 154-183. https://doi.org/10.1590/1678-69712016/administracao.v18n2p154-183

Fuertes-Callén, Y., Cuellar-Fernández, B., \& Pelayo-Velázquez, M. (2014). Determinants of online corporate reporting in three Latin American markets: The role of web presence development. Online Information Review, 38(6), 806-831. https://doi.org/10.1108/OIR-10-2013-0240

Hair, J., Black, W., Babin, B., \& Anderson, R. (2014). Multivariable data analysis (7th ed.). Pearson Education Limited.

Hossain, M., Momin, M. A., \& Leo, S. (2012). Internet financial reporting and disclosure by listed companies: Further evidence from an emerging country. Corporate Ownership and Control, 9(4), 351-366.https://doi.org/10.22495/cocv9i4c3art6

Joshi, P. L., \& Al - Modhahki, J. (2003). Financial reporting on the internet: Empirical evidence from Bahrain and Kuwait. Asian Review of Accounting, 11(1), 88-101. https://doi.org/10.1108/eb060764

JSC. (2017). Instructions of Corporate Governance for Shareholding Listed Companies for the year 2017. Retrieved from https://jsc.gov.jo/Links2/en/instructions

Keliwon, K. B., Shukor, Z. A., Mohamed, Z. M., \& Hassan, M. S. (2014). Exploring internet financial reporting (IFR) strategies of firms in Malaysia. Management \& Accounting Review (MAR), 13(2), 1-21.

Khadaroo, I. M. (2005). Business reporting on the internet in Malaysia and Singapore: A comparative study. Corporate communications: An international Journal, 10(1), 58-68. https://doi.org/10.1108/13563280510578204

Khan, M. N. A. A. (2016). Disclosure Items of Internet Financial Reporting: Malaysian Users Perceptions. International Business Management, 10(18), 4090-4097. 
Khan, M., \& Ismail, N. A. (2011). The Use of Disclosure Indices in Internet Financial Reporting Research. Journal of Global Business and Economics, 3(1), 157-173. https://doi.org/10.5171/2012.798113

Khan, M. N. A. A., \& Ismail, N. A. (2012). Bank Officers' Views of Internet Financial Reporting in Malaysia. Procedia-Social and Behavioral Sciences, 57, 75-84. https://doi.org/10.1016/j.sbspro.2012.09.1160

Khan, M. N. A. A., Ismail, N. A., Mardani, A., Zavadskas, E. K., \& Kaklauskas, A. (2017). Empirical research of users' opinions on selected aspects in internet financial reporting. Ekonomie and Management, 20(2), 146-162.https://doi.org/10.15240/tul/001/2017-2-011

Khan, M. N. A. A., Ismail, N. A., \& Zakuan, N. (2013). Benefits of internet financial reporting in developing countries: Evidence from Malaysia. African Journal of Business Management, 7(9), 719-726.

Lee, A., Neilson, J., Tower, G., \& Van der Zahn, J. L. M. (2007). Is communicating intellectual capital information via the internet viable? Journal of Human Resource Costing \& Accounting, 11(1), 53-78. https://doi.org/10.1108/14013380710746401

Lodhia, S. K., Allam, A., \& Lymer, A. (2004). Corporate reporting on the internet in Australia: An exploratory study. Australian Accounting Review, 14(34), 64-71. https://doi.org/10.1111/j.1835-2561.2004.tb00242.x

Lymer, A., Debreceny, R., Gray, G. L., \& Rahman, A. (1999). Business Reporting on the Internet: A Report Prepared for the International Accounting Standards Committee. IASC.

Marston, C. (2003). Financial reporting on the internet by leading Japanese companies. Corporate communications: An International Journal, 8(1), 23-34. https://doi.org/10.1108/13563280310458894

Marston, C., \& Polei, A. (2004). Corporate reporting on the Internet by German companies. International Journal of Accounting Information Systems, 5(3), 285-311. https://doi.org/10.1016/j.accinf.2004.02.009

Momany, M. T., \& Al-Shorman, S. A. D. (2006). Web-based voluntary financial reporting of Jordanian companies. International Review of Business Research Papers, 2(2), 127-139.

Momany, M. T., Al-Malkawi, H. A., \& Mahdy, E. (2014). Internet financial reporting in an emerging economy: evidence from Jordan. Journal of Accounting in Emerging Economies, 4(2), 158-174. https://doi.org/10.1108/JAEE-04-2012-0015

Nel, G., \& Baard, R. (2019). Minimum corporate website disclosure levels and information asymmetry: Evidence from Johannesburg Stock Exchange small-cap companies. South African Journal of Accounting Research, 33(3), 187-204. https://doi.org/10.1080/10291954.2019.1662210

Ojah, K., \& Mokoaleli-Mokoteli, T. (2012). Internet financial reporting, infrastructures and corporate governance: An international analysis. Review of Development Finance, 2(2), 
69-83. https://doi.org/10.1016/j.rdf.2012.04.001

Omran, M. A., \& Ramdhony, D. (2016). Determinants of internet financial reporting in African markets: The case of Mauritius. The Journal of Developing Areas, 50(4), 1-18. https://doi.org/10.1353/jda.2016.0150

Pinto, I., \& Picoto, W. N. (2016). Configurational analysis of firms' performance: Understanding the role of Internet financial reporting. Journal of Business Research, 69(11), 5360-5365. https://doi.org/10.1016/j.jbusres.2016.04.138

Pirchegger, B., \& Wagenhofer, A. (1999). Financial information on the Internet: A survey of the homepages of Austrian companies. European Accounting Review, 8(2), 383-395. https://doi.org/10.1080/096381899336113

Portella, A. R., \& Bora, J. A. A. (2020). Environmental disclosure in corporate websites: A study in Brazil and USA companies. RAUSP Management Journal, 55(3), 309-324. https://doi.org/10.1108/RAUSP-07-2018-0053

Puspitaningrum, D., \& Atmini, S. (2012). Corporate governance mechanism and the level of internet financial reporting: Evidence from Indonesian companies. Procedia Economics and Finance, 2, 157-166. https://doi.org/10.1016/S2212-5671(12)00075-5

Sánchez, I. M. G., Domínguez, L. R., \& Álvarez, I. G. (2011). Corporate governance and strategic information on the internet: A study of Spanish listed companies. Accounting, Auditing \& Accountability Journal, 24(4), 471-501. https://doi.org/10.1108/09513571111133063

Sandhu, A., \& Singh, B. (2019). Board composition and corporate reporting on internet: Indian evidence. Journal of Financial Reporting and Accounting, 17(2), 292-319. https://doi.org/10.1108/JFRA-05-2017-0031

Sarea, A. M. (2020). Web-based Financial Reporting Disclosure: Evidence from Selected Banks in the Kingdom of Saudi Arabia (KSA). Journal of Central Banking Theory and Practice, 9(2), 183-197. https://doi.org/10.2478/jcbtp-2020-0019

Sekaran, U., \& Bougie, R. (2016). Research methods for business: A skill building approach. John Wiley \& Sons.

Smith, B., \& A, Pierce (2005). An Investigation of the Integrity of Internet Financial Reporting. The International Journal of Digital accounting Research, 5(9), 47-78. https://doi.org/10.4192/1577-8517-v5_2

Sriram, R. S., \& Laksmana, I. (2006). Corporate Web Site Reports: Some Evidence on Relevances and Usefulness. Information Resources Management Journal (IRMJ), 19(3), 1-17. https://doi.org/10.4018/irmj.2006070101

Tarik, Z., Azra, Z., \& Anela, F. (2015). Internet financial reporting in Bosnia and Herzegovina. Economic Review: Journal of Economics \& Business, 13(2), 21-35.

Trabelsi, S., Labelle, R., \& Laurin, C. (2004). CAP Forum on E-Business: The Management 


\section{Macrothink}

of Financial Disclosure on Corporate Websites: A Conceptual Model. Accounting Perspectives, 3(2), 235-259. https://doi.org/10.1506/UQXT-3L0K-N9XK-99E1

Victoria, B., \& Nicoleta, P. D. (2008). Online financial reporting disclosure requirements across central and Eastern European countries. Economic Science Series, 17(3), 984-991.

Wagner, S. M. (2006). Supplier development practices: An exploratory study. European Journal of Marketing, 40(5/6), 554-571. https://doi.org/10.1108/03090560610657831

Waweru, N., Mangena, M., \& Riro, G. (2019). Corporate governance and corporate internet reporting in sub-Saharan Africa: the case of Kenya and Tanzania. Corporate Governance: The International Journal of Business in Society, 19(4), 751-773. https://doi.org/10.1108/CG-12-2018-0365

Williams, S. M., \& Pei, C. A. H. W. (1999). Corporate social disclosures by listed companies on their web sites: an international comparison. The International Journal of Accounting, 34(3), 389-419. https://doi.org/10.1016/S0020-7063(99)00016-3

Yao, L. J., Nurunnabi, M., \& Hossain, M. A. (2012). The voluntary disclosure of internet financial reporting (IFR) in an emerging economy: a case of digital Bangladesh. Journal of Asia Business Studies, 6(1), 17-42. https://doi.org/10.1108/15587891211190688

Yassin, M. M. (2017). The determinants of internet financial reporting in Jordan: Financial versus corporate governance. International Journal of Business Information Systems, 25(4), 526-556. https://doi.org/10.1504/IJBIS.2017.085176

Zahra, S. A. (1990). Increasing the board's involvement in strategy. Long Range Planning, 23(6), 109-117. https://doi.org/10.1016/0024-6301(90)90108-G

\section{Copyrights}

Copyright for this article is retained by the author(s), with first publication rights granted to the journal.

This is an open-access article distributed under the terms and conditions of the Creative Commons Attribution license (http://creativecommons.org/licenses/by/4.0/). 